\title{
Perfecting Analysis of the Logistics Market Access Legal System in Our Country
}

\author{
Juntao Zhang \\ Weinan Normal University, Weinan, 714000, China
}

Keywords: Logistics Market; Access System; Laws and Regulations; Problem Analysis

\begin{abstract}
The ever-changing network information technology has given birth to the rapid development of e-commerce. The consequent logistics service industry has become more and more prominent in various industries in our country. It is regarded as the "third profit source" in the economic field. However, despite the rapid development of the logistics industry, the development of related supporting systems has lagged far behind and has even become a bottleneck in the development of the logistics industry, such as the legal system for the entry of the logistics market. At present, Chinese logistics market access legal system, there are still many problems, such as low level of legal effectiveness, the legislation is not uniform, the lack of necessary regulation and so on. Therefore, it is necessary to strengthen the research on the legal system of logistics market access and provide system guarantee for the stable development of the logistics market so as to improve the comprehensive competitiveness of Chinese logistics industry. The article mainly analyzes the existing problems in the legal system of the logistics market access in our country and puts forward the specific solutions.
\end{abstract}

\section{The Related Concepts Analysis of Logistics Market Access System}

The so-called logistics market access refers to the conditions under which logistics enterprises to obtain permission to enter the logistics market, logistics enterprises to participate in market activities must have the appropriate conditions. Domestic enterprises to enter the logistics market need to have two substantive and procedural conditions, of which the substantive conditions refer to the legal conditions of enterprises, domestic enterprises must become a corporate legal person before they can operate the logistics services; procedural conditions are the need to perform specific procedures to obtain The corresponding qualifications to enter the logistics market to operate logistics services; not only domestic-funded enterprises need to have the above conditions, the same applies to foreign-funded enterprises to enter the domestic logistics market. In addition, some special industries require special conditions, which are common practice in various countries in the world. The access system is the national legislature, the relevant administrative agencies through the form of legislation on the logistics company to enter the logistics business logistics services projects have to make a series of conditions, we can see that the logistics enterprise market access system is for logistics Enterprises set up to restrain the legal acts of its provisions, which reflects the mandatory, extensive, authoritative characteristics.

\section{The Important Role of the Logistics Market Access Legal System}

At the present stage of the rapid development of the logistics industry in our country, a fair, transparent and efficient legal system environment is a necessary measure to ensure the stable development of the logistics industry. Specifically, its important role lies in the following aspects:

First, regulate the main body of the logistics market. After establishing the market access system, some logistics enterprises that are not qualified and do not have relevant qualifications can not enter the market for business activities, and can eliminate fraud, optimize the overall logistics market entities and ensure the quality of the market entities to the largest extent, Maintain a healthy and orderly logistics market. Second, optimize the allocation of logistics resources and promote industrial upgrading. In a specific period of social logistics resources are limited, the allocation is too scattered will waste resources, and scientific logistics market access system will design the 
relevant access qualification conditions, only with qualified business and experienced members of the Into the market, this elimination can eliminate outdated logistics capacity, improve the overall operational efficiency of the industry, the allocation of logistics resources to optimize and promote industrial upgrading and transformation. Finally, provide the basis for the supervision of the logistics market. In the process of logistics market operation, government departments should intervene and adjust so as to ensure the mere failure of the market mechanism. However, the regulation and intervention of the government have a problem of game with local interests. Therefore, a scientific and harmonious market access legal system will exert great influence on the government Regulatory behavior to be restrained to ensure that the government exercise its regulatory rights and promote the healthy development of the entire logistics market.

\section{The Problems of Chinese Logistics Market Access Legal System Construction}

The current logistics laws and regulations in our country cover a very wide range of areas including warehousing, transportation, distribution, packaging, distribution, processing and so on. The different operational links are determined by the corresponding laws, administrative regulations, local laws and regulations and regulations The operation of the constraints, and for the logistics industry as a whole professional regulations are few, especially the logistics market access system is the lack of a unified system of institutions. Specifically, Chinese logistics market access legal system there are still the following aspects:

Analysis of Chinese current logistics market access laws and regulations system specifically for the logistics industry system of legal provisions is still blank, the existing "logistics industry restructuring and rejuvenation plan" belongs to the state administrative regulations, does not belong to the legal system areas; and which did not The market access issues to make specific norms and adjustments, the rest of the logistics for other areas to develop laws and regulations are mostly for different issues, formulated at different times, and more ways, regulations, opinions and other forms of presentation, such legislation The situation has weakened the legal effect, which has a direct impact on the steady development of the logistics industry.

On the one hand, aviation and railway transport are monopolistic. The government is not only the regulator but also the operator of logistics service. The status quo of "both as a player and a judge" can not guarantee the fairness of market competition. On the other hand, the basic service of logistics There are many situations in which government regulation is absent and abuses of rights are serious, and there is a serious over-competition problem. And the logistics industry involves many functional departments of the government. Different departments implement the regulations in their respective systems during the regulatory process, and there are differences in interests among the departments Asymmetry of sex and information. It is precisely because the lack of universal access to logistics market and the principle of regional integration, and ultimately lead to failure of the threshold of logistics market access, the situation chaos, the follow-up of the steady operation of the logistics market is extremely unfavorable.

To some extent, the competition in the service industry is the competition between talent and management methods. The logistics industry is all in the intelligence-intensive and knowledge-intensive industries, which require higher qualification of practitioners. However, at present, the qualification regulations for logistics practitioners in our country are scattered in the regulations and rules of transportation and logistics. The wording is principled, and the operability is not strong, and there is no clear professional qualification requirement. In addition, there is a problem with the qualification examination of practitioners, and even the development of the logistics industry. However, at present, such personnel are scarce resources and most of the qualification requirements are rather vague, resulting in the lack of necessary guidance in the process of the examination of the logistics industry practitioners, leading to the low professional skills of practitioners in the logistics market, the overall quality is poor, poor service quality. 


\section{The Strategy to Improve Chinese Logistics Market Access Legal System}

In view of the existing problems in the legal system of logistics market access in our country, it is suggested to improve from the following aspects:

First of all, for the special logistics enterprises to establish the corresponding market access requirements. The so-called special logistics enterprises mainly refers to the natural monopoly industries, such as rail transport, air transport companies, etc., the national government is the main body of the right to operate such enterprises. In the 1990s, China carried out the reform of state-owned enterprises and realized the separation of the ownership and management rights of state-owned enterprises. It improved the corporate governance structure with modern enterprise management theory. This reform broke the natural monopoly and pushed the market to optimize the allocation of resources The role of justice play out. In view of the status quo of special logistics market access, we can draw lessons from this experience to separate the management rights of railway and air transport from the ownership structure, apply loose control methods, and introduce non-public ownership and foreign investment entities to improve the corporate governance structure. Second, improve third-party logistics business legislation. Clarify the legal concept of "third-party logistics" and standardize the name of the third-party logistics enterprises; incorporate the main body of foreign-funded third-party logistics enterprises into the legislation of domestic-funded logistics enterprises to formulate a set of comprehensive, detailed and international standards tripartite logistics business qualification management requirements. In addition, third-party logistics enterprises should organize the form, registered capital, personnel management, business scope, etc. to be standardized to eliminate low-capacity logistics enterprises in order to enhance the industry's overall compliance capacity. Finally, improve local single-line legislation. Because of the unbalanced economic development in our country, there are big differences in the scale and level of logistics development in different regions. Therefore, we not only need to establish a nationwide system of logistics laws and regulations, but also establish a set of logistics regulations in line with local conditions. In addition, it is necessary to break down the limitations of the industry and strengthen the coordination among various places, which can not only provide the basis for establishing a nationwide logistics legal system, but also promote the development of enterprises across regions and industries.

Therefore, the establishment of basic principles is crucial. Under the guidance of the four principles of "Market Regulation Law" such as "Honesty, Credit, Fair and Reasonable Competition, Protection of Consumer Interests, and Maintenance of Market Order," the logistics market Access to the system to follow the following basic principles: First, the principle of moderate intervention. National functional departments should ensure the balance between the benefits and costs of each type of logistics transaction market through moderate intervention so as to avoid over-lenient micro-regulation and over-stringent macro-regulation. No matter whether it is natural monopoly or excessive competition, social welfare will have a negative impact. Therefore, the construction of logistics market access system must follow the principle of fair competition and ensure that all market players have equal legal status, equal rights and obligations, and equal market opportunities. Following the principle of safety and efficiency, the legal system of logistics market access can improve the service capability of market players, ensure the service quality of the industry and promote the stable development of modern logistics. Social responsibility is the highest point of administrative intervention is the basic starting point, the regulatory authorities in the access decision-making to fully assess whether the market main body can fulfill the corresponding social responsibility, will have an impact on the interests of others and the community as a whole.

The development of modern logistics industry is inseparable from the high-quality personnel support; it is necessary to strengthen the qualification of logistics practitioners. On the one hand, to encourage multi-level and multi-faceted logistics education and training, enterprises should strengthen cooperation with universities and vocational and technical colleges, increase investment in education funds, set up specialized logistics management major and train logistics professionals. In the logistics technology education, management consulting and other aspects of international 
logistics personnel to strengthen cooperation in education, enabling professionals to learn more about cutting-edge industry knowledge theory. On the other hand, to establish a unified legal rules for the qualification of logistics practitioners, improve the certification body, conditions, specific procedures and evaluation system with reference to the legal vocational qualification examination system, establish and improve the introduction mechanism and elimination mechanism of logistics personnel, and optimize the logistics market of human resources for the development of logistics market to train high-quality personnel.

\section{Conclusion}

In short, a sound logistics market access legal system is to ensure the stable development of the logistics industry an important condition, but the impact of the logistics market access legal system also includes factors such as policy, market regulation, human resources, economic status and the level of information, etc. Therefore, it is necessary to fully consider all aspects of the operation of the logistics industry, give full play to the roles of all fields, and integrate scientific and technological operations such as economy, law and policy to break the bottleneck in the development of Chinese logistics industry at this stage and promote the rapid development of Chinese logistics industry.

\section{Acknowledgements}

Fund Project: Shaanxi Province in 2017 military and civilian integration research fund project: Shaanxi province military and civilian integration emergency logistics management system.

\section{References}

[1] Zhaoqing Qing. A New Perspective of the Theoretical Basis of Market Access System [J]. Business Times, 2015, (2): 276-277

[2] Ma Tao. On the Improvement of Chinese Logistics Industry Policy and Law System [J]. Logistics Technology, 2017, (9): 85-86

[3] Song Yuping. Analysis of American Logistics Legal System [J]. China Goods and Purchase, 2015, (20): 306-307

[4] Liu Jingfu. Five contradictions among the third-party logistics enterprises in China [J]. Transportation Manager World, 2016, (4): 98-99

[5] Chen Bin. WTO system on the development of Chinese logistics legal system [J]. International Economic and Trade Exploration, 2014, (4): 110

[6] Xie Hui. Discussion on Establishing Market Rules for Storage Logistics [J]. China Transport and Storage, 2017, (9): 275-276

[7] Liu Bing sickle, Lu Yan. Journal of Logistics and Information Technology, 2017,2 (2): 38-40 Comment on the Credit Problem and Regulating System of Third-party Logistics in China [J]. Logistics Technology, 2017,2 (2): 38-40 